\title{
Endogenous controls in human umbilical vein endothelial cells under metabolic and oxidative stress
}

\author{
Sherin Bakhashab ${ }^{1,2,3}$, Sahira Lari ${ }^{2}$, Farid Ahmed ${ }^{3}$, Hans-Juergen Schulten ${ }^{3}$, Manikandan Jayapal ${ }^{4}$, Sajjad Karim ${ }^{3}$, \\ Ayat Bashir ${ }^{1}$, Fahad Ahmed ${ }^{1}$, Abdulrahman Al-Malki ${ }^{2}$, Hasan S Jamal ${ }^{5}$, Mamdooh Gari ${ }^{3}$, Mohammed H. Alqahtani ${ }^{3}$, \\ loakim Spyridopoulos ${ }^{1}$, Jolanta $\cup$ Weaver ${ }^{1 *}$
}

From 2nd International Genomic Medical Conference (IGMC 2013)

Jeddah, Kingdom of Saudi Arabia. 24-27 November 2013

\section{Background}

Gene expression studies on the effect of hypoxia and hyperglycemia using human umbilical vein endothelial cell (HUVEC) cultures are of particular interest in cardiovascular disease and diabetes. Normalization of gene expression data refers to the comparison of expression values using endogenous control that is steady across independent experimental conditions, a crucial step for gene expression studies. The endogenous controls for experiments involving hyperglycemia, hypoxia and a combination of the two have not been identified before in HUVEC. Our objective was to identify endogenous controls that are stable under oxidative (hypoxia) and metabolic stress (hyperglycemia) in HUVEC.

\section{Materials and methods}

We applied human genome-wide expression array using Affymetrix ${ }^{\mathbb{B}}$ GeneChip $^{\mathbb{B}}$ on mRNA obtained from 3 different primary HUVEC cultures incubated in euglycemic (5.5 $\mathrm{mM}$ ) or hyperglycemic conditions $(16.5 \mathrm{mM})$ and/or in chemical hypoxia induced by $150 \mu \mathrm{M}$ Cobalt Chloride for 1, 3, 12 hours.

\section{Results}

Microarray data showed that 9560 genes were identified as potential endogenous controls under hypoxia, hyperglycemia, and hyperglycemia combined with hypoxia. Subsequently, the RNA expression level of 5 endogenous controls was validated by real-time quantitative PCR
(qRT-PCR) to confirm the stability of the expression. The following endogenous controls were identified as the most stable: under hyperglycemia ribosomal protein, large, P0 (RPLP0), and transferrin receptor (TFRC), Glyceraldehyde-3-phosphate dehydrogenase (GAPDH), glucuronidase, beta (GUSB), and $\beta$-actin, under hypoxia alone RPLP0, and TFRC whereas under hyperglycemia combined with hypoxia RPLP0, TFRC, GUSB, and $\beta$-actin.

\section{Conclusions}

Our data demonstrate that RPLP0 and TFRC are the most suitable endogenous controls analyzed for expression studies utilizing HUVEC cultured under metabolic or oxidative stress at $1 \mathrm{~h}, 3 \mathrm{~h}$, and $12 \mathrm{~h}$ time points. The other genes were detected to be stable at the short-term but not after long-term exposure to hypoxia.

\section{Authors' details \\ ${ }^{1}$ Institute of Cellular Medicine, Newcastle University, Newcastle, UK. ${ }^{2}$ Biochemistry Department, King Abdulaziz University, Jeddah, KSA. ${ }^{3}$ Centre of Excellence in Genomic Medicine Research, King Abdulaziz University, Jeddah, KSA. ${ }^{4}$ Faculty of Science, The University of Western Australia, Crawley, Australia. ${ }^{5}$ Department of Obstetrics \& Gynecology Faculty of Medicine King Abdulaziz University, Jeddah, KSA.}

Published: 2 April 2014

References

1. Dheda K, Huggett JF, Bustin SA, Johnson MA, Rook G, Zumla A: Validation of housekeeping genes for normalizing rna expression in real-time pcr. Biotechniques 2004, 37:112-114, 116, 118-9.

2. Huggett J, Dheda K, Bustin S, Zumla A: Real-time rt-pcr normalisation; strategies and considerations. Genes Immun 2005, 6:279-284.

* Correspondence: J.U.Weaver@ncl.ac.uk

${ }^{1}$ Institute of Cellular Medicine, Newcastle University, Newcastle, UK

Full list of author information is available at the end of the article 
doi:10.1186/1471-2164-15-S2-P23

Cite this article as: Bakhashab et al:: Endogenous controls in human umbilical vein endothelial cells under metabolic and oxidative stress. BMC Genomics 2014 15(Suppl 2):P23.

Submit your next manuscript to BioMed Central and take full advantage of:

- Convenient online submission

- Thorough peer review

- No space constraints or color figure charges

- Immediate publication on acceptance

- Inclusion in PubMed, CAS, Scopus and Google Scholar

- Research which is freely available for redistribution

Submit your manuscript at www.biomedcentral.com/submit 